\title{
Efficacy of the closed suction applied to patients in intensive care units with different techniques: A nonrandomized controlled trial
}

\section{Farklı tekniklerle yoğun bakım ünitelerinde hastalara uygulanan kapalı aspirasyonun etkinliği: Randomize olmayan kontrollü çalışma}

Zuhall Güilsoy, BSc, MSc, RN, ${ }^{1}$ Şerife Karagözoğlu, BSc, MSc, PhD, RN, ${ }^{2}$

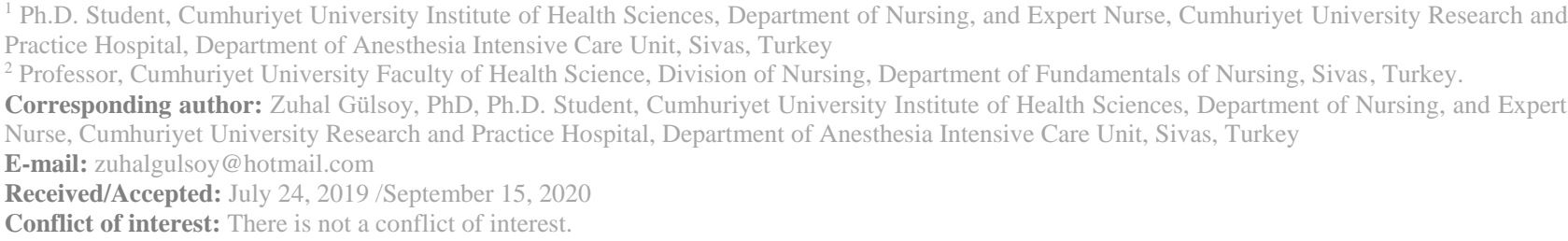

\section{SUMMARY}

Objective: The present study was conducted to investigate the effects of the closed suction system and different suction techniques in which oxygen and saline instillation were administered individually or in combination on the efficacy of suction, cardiopulmonary indicators, feelings and pain experienced by patients after suction.

Method: This study was planned as an experimental and cross-sectional one. The study had a single group, and a pre- and post-test design $(n=43)$. This study was planned as a single blind in line with the Transparent Reporting of Evaluations with Nonrandomized Designs (TREND). The study data were collected using the Data Collection Form aiming to assess hemodynamics, cardiopulmonary indicators and comfort and the Visual Analog Scale for Pain to assess pain. Parameters were measured before, during and at the $1^{\text {st }}, 3^{\text {rd }}, 5^{\text {th }}, 7^{\text {th }}$ and $10^{\text {th }}$ minutes after suction using different techniques, and the patients were asked how they felt during the suction. Although the processes were implemented by the researcher, data were recorded not by the researcher but by the other two nurses who voluntarily worked at the clinic.

Results: It was found that the standard suction technique could be better tolerated. The administration of oxygen and saline instillation before suction individually or in combination caused anxiety in patients and affected study parameters statistically significantly.

Conclusions: There was a statistically significant difference between aspiration with SI and other aspiration methods, but this difference was still within normal limits. The patients drew attention to relaxation after suction despite the discomfort they experienced during suction, it can be said that tracheal suction has a vital importance in ensuring the maintenance of airway patency and oxygenation, even though it is a discomforting and painful procedure.

Keywords: Closed endotracheal suctioning, hemodynamic effects, oxygen saturation, pain, saline instillation.
Zuhal Gülsoy

Şerife Karagözoğlu

ORCID IDs of the authors: Z.G. 0000-0002-6866-5215 Ş.K. 0000-0002-9558-0786 
ÖZET

Amaç: Bu çalışma, kapalı aspirasyon işleminde oksijen ve serum fizyolojiğin (SF) tek tek veya kombinasyon halinde uygulandığı farklı aspirasyon tekniklerinin, aspirasyon etkinliği, kardiyopulmoner göstergeler, aspirasyon sonrası hastaların hissettiği duygu ve ağrı üzerine etkilerini araştırmak amacıyla yapılmıştır.

Yöntem: Bu çalışma deneysel ve kesitsel olarak planlanmıştır. Çalışma tek bir gruba ön ve son test tasarımına sahiptir (n =43). Bu çalışma, Randomize Olmayan Tasarımlar ile Değerlendirmelerin Şeffaf Raporlanması (TREND) doğrultusunda tek kör olarak planlanmıştır. Çalışma verileri olarak hemodinamik parametreler, kardiyopulmoner göstergeler, ağrı skorları ve hasta konforu veri toplama formuna kaydedildi. Ağrıyı değerlendirmek için Görsel Analog Ağrı Ölçeği kullanılmıştır. Farklı teknikler kullanılarak aspirasyon öncesi, işlem sırası ve işlem sonrası 1., 3., 5., 7. ve 10. dakikalarda parametreler ölçülerek hastalara aspirasyon sırasında nasıl hissettikleri soruldu. Süreçler araştırmacı tarafindan uygulanmasına rağmen veriler araştırmacı tarafından değil, klinikte gönüllü olarak çalışan diğer iki hemşire tarafindan kaydedilmiştir.

Bulgular: Standart aspirasyon tekniğinin daha iyi tolere edilebileceği bulundu. Tek tek veya kombinasyon halinde aspirasyon öncesi oksijen ve SF uygulaması, hastalarda anksiyeteye neden oldu ve çalışma parametrelerini istatistiksel olarak anlamlı şekilde etkiledi.

Sonuç: SF kullanılarak yapılan aspirasyon ile diğer aspirasyon yöntemleri arasında istatistiksel olarak anlamlı bir fark vardı, ancak bu fark normal sınırlar içindeydi. Hastalar aspirasyon sırasında yaşadıkları rahatsızlığa rağmen aspirasyon sonrası rahatlamaya dikkat çektiler. Rahatsız edici ve ağrılı bir işlem olmasına rağmen trakeal aspirasyon hava yolu açıklığının ve oksijenlenmenin sürdürülmesinde hayati bir öneme sahiptir.

Anahtar sözcükler: Kapalı endotrakeal aspirasyon, hemodinamik etkiler, oksijen satürasyonu, ağrı, serum fizyolofik.

\section{INTRODUCTION}

The primary condition for respiration to occur normally is that airway should be open 1 . Endotracheal intubation and mechanical ventilation (MV) in patients with respiratory failure are life-saving interventions ${ }^{2-4}$, and maintenance of airway patency requires endotracheal suction ${ }^{5-7}$.

Presence of intubation increases the secretion production in the respiratory tract ${ }^{8-10}$ and patients cannot clear these secretions from their respiratory tract by themselves. Thus, accumulation of secretions in the respiratory tract can lead to mechanical obstructions and suctioning of the patient becomes inevitable depending on the patient's need ${ }^{11}$.

Although tracheal suction is an indispensable requirement for airway patency, it can bring about many undesired conditions. In the literature, endotracheal suction, an invasive intervention, has been shown to cause several complications such as discomfort, pain, hemorrhage, infection, bronchospasm, cardiovascular instability, hypoxia / hypoxemia 12-16. However, selection of an appropriate and effective suction technique can reduce the incidence of acute complications ${ }^{17}$. In this context, it is important to evaluate the suction technique applied to patients undergoing MV in ICUs, and the results of suction.

This present study was carried out to investigate the effects of the administration of oxygen and saline instillation (SI) individually or in combination in the closed suction system to patients connected to the MV in the anesthesia intensive care unit on the efficacy of the suction, cardiopulmonary indicators, feelings and pain experienced by the patient after suction.

\section{MATERIAL AND METHODS}

Design: The study had a single group, and a preand post-test design-This study was planned as a single blind in line with the Transparent Reporting of Evaluations with Nonrandomized Designs (TREND) (See Supplementary File 1). The individuals in the sample group constituted both the experimental group and the control group. All the patients $(n=43)$ who were admitted to the intensive care unit where the study was conducted for six months and who met the study criteria were included in the study.

Place of the Study: The research was carried out in the Anesthesia Intensive Care Unit. The suctioning process in which four different suction techniques were applied successively was completed within a maximum of three days in accordance with the suction needs of the patients. During the assessment, each patient's pulse rate, respiratory rate, blood pressures (systolic, diastolic, mean), end-tidal carbon dioxide (EtCO2), saturation levels (SPO2), the ECG rhythm, compliance, resistance, and peak inspiration pressure (Ppeak) values read on the monitor before, during and at the $1^{\text {st }}, 3^{\text {rd }}, 5^{\text {th }}, 7^{\text {th }}$ and $10^{\text {th }}$ minutes after each suction were recorded. 
Study Population: All the patients admitted to the anesthesia intensive care unit of a university hospital, between December 01, 2015 and June 01, 2016 comprised the population of the study. The study had a single group, and a pre- and post-test design. Of the patients who met the inclusion criteria at the beginning of the study, 5 were excluded due to following reasons: 2 were extubated, and 3 were administered inotropic agents and sedated due to disruption in their general health conditions.

The inclusion criteria: The inclusion criteria were as follows: (1) being connected to the MV (2) having an endotracheal tube or tracheotomy cannula, (3) being over 18 years of age, (4) being hemodynamically stable, (5) having a Glasgow Coma Score (GCS) of 15 and being able to communicate (6) not taking an inotropic agent, (7) not being administered sedation/analgesic medication (8) not having bronchospasm.

Exclusion Criteria: The exclusion criteria were as follows: (1) having a permanent neuromuscular disease, (2) meeting the inclusion criteria at the beginning of the study but not during the study (3) being diagnosed with Alzheimer's disease which might negatively affect his/her communication.

Data Collection: Each patient in the study was aspirated with the following four different suction techniques in the following order when the patient needed suction: (1) suction (standard) without administering SI and 100\% oxygen, (2) suction with $100 \%$ oxygen alone, (3) suction with SI alone, and (4) suction with SI and $100 \%$ oxygen in combination. In order for the study results not to be influenced by factors such as Hemoglobin fever, MV settings, different suction techniques were applied to each patient on the same day taking his/her need for suction into account. If this was not possible on the same day, suction was performed in the following days as long as the patient displayed the same clinical conditions. General application steps for all the aspiration techniques and applications which changed in each technique are given in Chart.

The patients included in the study were aspirated using the closed suction system when they needed suction. The catheter used in the present study is the Ty-Care Brand 16-French thick catheter available in our hospital which is routinely used in patients undergoing MV in the ICU. The Medela AG, Medical Technology Dominant 506341 BAAR-Switzerland aspirator which had a vacuum power of $-120 \mathrm{mmHg}$ was used as a negative pressure source in each application. Other parameters were recorded from the EvitaXL SW 6.1n (C) Drager Medical AG \& Co. Germany Brand MV and the Infinity Delta Series VF8 (C) Drager Medical Systems, Inc. US Branded bed side monitor used in the ICU.

Data Collection Form: This form was developed by the researchers based on the literature. The first part of the form questions sociodemographic characteristics and cardiopulmonary indicators. In the second part, the pulse rate, arterial blood pressure, respiratory rate, tidal volume (VT), Ppeak, $\mathrm{ETCO}_{2}, \mathrm{SPO}_{2}$ and VAS for Pain measured before, during and at the $1^{\text {st }}, 3^{\text {rd }}, 5^{\text {th }}, 7^{\text {th }}$ and $10^{\text {th }}$ minutes after the endotracheal suction for each technique were recorded. In the third part of the form, the patients were asked questions to find out how they felt during suction. This part developed by the researchers consists of the following seven yes/no questions: (1) Did you experience pain during the suction? (2) Did you experience fear during the suction? (3) Did you have any nausea during the suction? (4) Did you experience shortness of breath during the suction? (5) Did you experience feelings of suffocation during the suction? (6) Did you have an urge to cough during the suction? (7) Did you feel more comfortable after the suction than you did before the suction?

During the suction, all the assessment were performed and records were kept not by the researcher but by the other two nurses who worked voluntarily at the clinic, which ensured data to be more objective. The staff member performing the assessments was not involved in implementing any aspect of the intervention and knew the participants only by their pseudonyms.

Visual Analogue Scale (VAS) fo Pain : The VAS was developed by Selby et al. (1984) ${ }^{18}$ to assess quality of life in cancer patients. The VAS for Pain has been used in many studies evaluating different parameters since 1990s and has recently been used to measure special conditions such as pain. This measurement tool is reliable and easily applicable. It is a well-accepted tool in the world literature. It has a ten-centimeter line with the left end corresponding to "no pain" and the right end corresponding to "worst possible pain". The patient marks a point on the line corresponding to the severity level of his/her pain ${ }^{19}$.

Ethical considerations: Prior to the study, Ethics committee approval was obtained. Written permission to conduct the study was obtained from the hospital where the study was to be performed. The study was conducted according to the principles of the Helsinki Declaration. The patients and their first degree relatives included in the study were informed about the study and their informed 
consent indicating that they agreed to participate in the study was obtained.

Statistical analyses: The data obtained in the study were analyzed using the SPSS (Version 22.0). When the parametric test assumptions were met (Kolmogorov-Simirnov), the Variance Analysis was used for the comparison of more than two independent groups in terms of one variable obtained through measurement. The Repeated Measures Analysis of Variance was used when more than two measurement values obtained at different times were compared, and the Bonferroni test was used when the difference in measurement values was significant. When the parametric test assumptions were not met, the Mann Whitney U test was used for the comparison of the two independent groups in terms of one variable obtained through measurement, the Kruskal-Wallis test was used for the comparison of more than two independent groups, the Friedman test was used when more than two measurement values obtained at different times were compared and the Wilcoxon test was used to find out from which measurements the difference stemmed when at least one measurement was different from the others according to the analysis results. The data were given as mean \pm , standard deviation, and the number and percentage of individuals. The margin of error was accepted as $\mathrm{p}=0.05$.

In the present study, the efficacy of tracheal suction was assessed by taking into consideration whether there was an increase in $\mathrm{SPO}_{2}$ and compliance, and whether there was a decrease in the $\mathrm{EtCO}_{2}$, airway resistance and peak inspiratory pressure. The parameters used to assess a patient's discomfort level caused by tracheal suction with different techniques are as follows: That the pulse rate and regularity, respiration rate, arterial blood pressure values obtained from these measurements are similar to or a little lower than those obtained in the initial measurements, that $\mathrm{SPO}_{2}$ value is similar to or higher than that obtained in the initial measurements, and that the $\mathrm{EtCO}_{2}$ value is lower than that obtained in the initial measurements suggest that the technique applied was appropriate.

\section{RESULTS}

Demographic Characteristics of Patients: The data on the patients included in the study in terms of the variables such as age, sex and hospitalization days revealed that their mean age was $62.44 \pm$ $15.58,53.2 \%$ of them were female and their mean duration of hospitalization was $7.11 \pm 9.91$ days.

VT, Compliance, Resistance and Ppeak Results Regarding the Efficacy of Suction in Different Suction Techniques: The mean VT scores of the participants did not vary statistically significantly in all the suction techniques ( $p>0.05$ ) except for the technique in which SI and oxygen were administered in combination $(\mathrm{p}=0.01)$, In all the suction techniques, although the VT values of the patients decreased within normal limits during the suction, these values measured at the 1st minute after the suction were above the baseline values. These results showed that all the suction techniques were effective (Figure 1).

The difference between the compliance and Ppeak scores of the patients (Figure 1) was statistically insignificant in each suction technique ( $p>0.05)$. In the present study, in general, the resistance values decreased significantly in all the suction techniques, which suggests that all the suction techniques were effective.

\section{Results Indicating the Effect of Different Suction Techniques on Hemodynamic Indicators $\left(\mathrm{EtCO}_{2}, \mathrm{SPO}_{2}\right.$, Respiratory Rate, Systolic and Diastolic Blood Pressure, Pulse Rate): $\mathrm{EtCO}_{2}$ scores were statistically insignificant in each suction technique ( $p>0.05)$; however, the difference between the mean scores was statistically significant in each suction technique $(p=0.001)$ (Figure 2$)$. In all the suction techniques, the patients' $\mathrm{EtCO}_{2}$ values measured during the suction was higher than all the other $\mathrm{EtCO}_{2}$ values measured at baseline and after the suction, except for the one measured at the $10^{\text {th }}$ minute after the suction, which was lower than the baseline value. All these results suggest that all the suction techniques were effective. The mean $\mathrm{SPO}_{2}$ values determined during the suctions with oxygen alone and with oxygen-SI combination (Figure 2) patients reached the highest level at the $1^{\text {st }}$ minute after the suction and the difference between the measurements was statistically significant $(\mathrm{p}<0.05)$.}

The difference between the mean respiratory and pulse rates in patients except for those undergoing suction with SI (Figure 2); was statistically insignificant $(p>0.05)$. The difference between systolic/diastolic blood pressure measurements was statistically significant in all the suction techniques except for the standard suction technique $(\mathrm{p}=0.052)(\mathrm{p}<0.05)$. In all the suction methods, an increase was observed in the systolic and diastolic blood pressures within normal limits during the suction, but the values measured at the $10^{\text {th }}$ minute after the suction were lower than were the baseline values.

Results Indicating the Effect of Suction Techniques on Feelings and Pain Experienced by the Patients: When the patients were asked 
about the feelings they experienced during the suction performed with different techniques, they responded that they experienced the least pain $(9.30 \%)$ and nausea $(30.23 \%)$ during normal suction and the least fear $(27.91 \%)$ during suction with SI and oxygen in combination. There was no statistically significant difference between the suction-related feelings (Table 1). There were statistically significant differences mean pain scores determined before, during and after the suction $\quad(\mathrm{p}<0.05) \quad($ Table 2). The patients experienced the highest level of pain during the suction.

Limitations of the Research: In order for variables such as MV mode, PEEP level, hemoglobin level, diagnosis etc. not to affect the study results, 4 different suction techniques were applied to the same patient when the patient's clinical condition did not change and when he/she needed suction. While this procedure took only one day in some patients, it took up to 3 days in the other patients.

Table 1: Distribution of the emotions of the patients during the application of different suction methods

\begin{tabular}{|c|c|c|c|c|c|c|c|c|c|c|c|c|c|c|c|c|}
\hline & \multicolumn{4}{|c|}{$\begin{array}{l}\text { Standard } \\
\text { Suction }\end{array}$} & \multicolumn{4}{|c|}{$\begin{array}{l}\text { With Oxygen } \\
\text { Suction }\end{array}$} & \multicolumn{4}{|c|}{$\begin{array}{l}\text { With SI } \\
\text { Suction }\end{array}$} & \multicolumn{4}{|c|}{$\begin{array}{c}\text { Oxygen-SI together } \\
\text { Suction }\end{array}$} \\
\hline & \multicolumn{2}{|r|}{ Yes } & \multicolumn{2}{|r|}{ No } & \multicolumn{2}{|c|}{ Yes } & \multicolumn{2}{|r|}{ No } & \multicolumn{2}{|r|}{ Yes } & \multicolumn{2}{|r|}{ No } & \multicolumn{2}{|r|}{ Yes } & \multicolumn{2}{|r|}{ No } \\
\hline & Count & Percent & Count & Percent & Count & Percent & Count & Percent & Count & Percent & Count & Percent & Count & Percent & Count & Percent \\
\hline Pain & 4 & 9.30 & 39 & 90.70 & 7 & 16.28 & 36 & 83.72 & 7 & 16.28 & 36 & 83.72 & 6 & 13.95 & 37 & 86.05 \\
\hline Fear & 13 & 30.23 & 30 & 69.77 & 18 & 41.86 & 25 & 58.14 & 17 & 39.53 & 26 & 60.47 & 12 & 27.91 & 31 & 72.09 \\
\hline Nausea & 13 & 30.23 & 30 & 69.77 & 16 & 37.21 & 27 & 62.79 & 18 & 41.86 & 25 & 58.14 & 14 & 32.56 & 29 & 67.44 \\
\hline $\begin{array}{l}\begin{array}{l}\text { Shortness } \\
\text { of breath }\end{array} \\
\end{array}$ & 19 & 44.19 & 24 & 55.81 & 23 & 53.49 & 20 & 46.51 & 27 & 62.79 & 16 & 37.21 & 19 & 44.19 & 24 & 55.81 \\
\hline $\begin{array}{l}\text { Feelings of } \\
\text { suffocation }\end{array}$ & 25 & 58.14 & 18 & 41.86 & 26 & 60.47 & 17 & 39.53 & 28 & 65.12 & 15 & 34.88 & 20 & 46.51 & 23 & 53.49 \\
\hline $\begin{array}{l}\text { Cough } \\
\text { reflex }\end{array}$ & 34 & 70.07 & 9 & 20.93 & 33 & 76.74 & 10 & 23.26 & 27 & 62.79 & 16 & 37.21 & 25 & 58.14 & 18 & 41.86 \\
\hline Relaxation & 43 & 100 & 0 & 0 & 43 & 100 & 0 & 0 & 42 & 97.67 & 1 & 2.33 & 41 & 95.35 & 2 & 4.65 \\
\hline
\end{tabular}

Table 2: Distribution of the Mean scores visual analogue scale for pain by the undergoing various suction methods before, during and after the suction

\begin{tabular}{|c|c|c|c|c|c|c|}
\hline & & $\begin{array}{c}\text { Standard } \\
\text { Suction } \\
X \pm \text { SD }\end{array}$ & $\begin{array}{c}\text { With Oxygen } \\
\text { Suction } \\
\text { X } \pm \text { SD }\end{array}$ & $\begin{array}{l}\text { With SI } \\
\text { Suction } \\
X \pm \text { SD }\end{array}$ & $\begin{array}{c}\text { Oxygen - SI } \\
\text { Together } \\
\text { Suction } \\
\mathbf{X} \pm \text { SD }\end{array}$ & Statistical Analysis \\
\hline \multirow{9}{*}{ 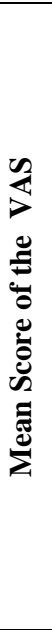 } & Baseline & $0.16 \pm 1.06$ & $0.20 \pm 0.96$ & $0.11 \pm 0.76$ & $0.16 \pm 1.06$ & $\begin{array}{c}\mathrm{KW}=0.58 \\
\mathrm{P}=0.904\end{array}$ \\
\hline & During & $0.51 \pm 1.76$ & $0.69 \pm 1.88^{\dagger}$ & $0.46 \pm 1.40^{\ddagger}$ & $0.55 \pm 1.60^{\dagger}$ & $\begin{array}{c}\mathrm{KW}=0.83 \\
\mathrm{p}=0.841\end{array}$ \\
\hline & \multicolumn{6}{|l|}{ After } \\
\hline & 1st minute & $0.13 \pm 0.41$ & $0.41 \pm 1.60$ & $0.25 \pm 1.00$ & $0.16 \pm 1.06$ & $\begin{array}{c}\mathrm{KW}=2.00 \\
\mathrm{p}=0.572\end{array}$ \\
\hline & 3rd minute & $0.09 \pm 0.60$ & $0.16 \pm 0.92$ & $0.16 \pm 0.92$ & $0.16 \pm 1.06$ & $\begin{array}{c}\mathrm{KW}=0.65 \\
\mathrm{p}=0.884\end{array}$ \\
\hline & 5th minute & $0.11 \pm 7.62$ & $0.11 \pm 7.62$ & $0.11 \pm 7.62$ & $0.16 \pm 1.06$ & $\begin{array}{c}\mathrm{KW}=0.59 \\
\mathrm{p}=0.897\end{array}$ \\
\hline & 7th minute & $0.13 \pm 0.91$ & $0.11 \pm 0.76$ & $0.16 \pm 0.92$ & $0.16 \pm 1.06$ & $\begin{array}{c}\mathrm{KW}=0.58 \\
\mathrm{p}=0.900\end{array}$ \\
\hline & 10th minute & $0.13 \pm 0.91$ & $0.11 \pm 0.76$ & $0.13 \pm 0.77$ & $0.16 \pm 1.67$ & $\begin{array}{c}\mathrm{KW}=0.56 \\
\mathrm{p}=0.904\end{array}$ \\
\hline & $\begin{array}{l}\text { Statistical } \\
\text { analysis }\end{array}$ & $\begin{array}{c}X^{2}=10.14 \\
p=0.144\end{array}$ & $\begin{array}{c}X^{2}=29.20 \\
p=0.010\end{array}$ & $\begin{array}{c}X^{2}=15.95 \\
p=0.014\end{array}$ & $\begin{array}{c}X^{2}=36.00 \\
p=0.001\end{array}$ & \\
\hline
\end{tabular}

${ }_{\mathrm{p}}^{\mathrm{p}}<0.05$; When the baseline compared with $1 \mathrm{st}, 3 \mathrm{rd}, 5$ th, 7 th, $10 . \mathrm{min}$ after the process

${ }^{\ddagger_{p}}<0.05$; When the baseline compared with 10 .min after the process 


\section{DISCUSSION}

\section{Discussion of the Results Indicating the Efficacy of Suction Techniques}

According to the VT results obtained from the present study, there was a decrease in VT values within normal limits during the suction in the patients in all the suction techniques, but the values obtained at the $10^{\text {th }}$ minute after the suction were above the baseline values. This decrease in VT values was related to the fact that during the suction, some air was aspirated besides secretion, and that there was a failure in inspiration because the suction catheter stimulated the cough reflex. However, the mean VT scores increased when the normal suction technique was applied (Figure 1). These results demonstrated that normal suction technique was better tolerated. However, when all VT results are taken into consideration, it can be said that all the suction methods were generally effective in the patients.

In the literature, the number of studies similar to the present study is limited. In their study investigating the physiological effects of closed suction system in patients breathing spontaneously with MV, Seymour et al. used the method closest to the method of the present study ${ }^{20}$ and found that the VT values decreased during suction and increased again from the first minute after the suction, as in our study.

According to the compliance results of the present study, the compliance values exhibited similar characteristics at all stages of the suction, while they were at the highest level at the baseline, they gradually decreased during and after the suction. However, it was noticed that the compliance values decreased statistically significantly at the $1^{\text {st }}$ and $7^{\text {th }}$ minutes after the suction in the patients $(\mathrm{p}<0.05)$ (Figure 1). In the present study, although it was expected that the compliance value determined after the suction would be higher than the baseline value, it gradually decreased, which might be related to the spasm in the pulmonary mucosa caused by the suction catheter's contact with the lung mucosa. As a matter of fact, it was observed that a certain time was needed to relieve the spasm. The decrease in compliance values is thought to result not from the method used but from the suction catheter.

In their study investigating the different effects of endotracheal suction in patients with ARDS undergoing volume and pressure controlled ventilation ${ }^{22}$, Liu et al. reported that compliance values were lower than the baseline values during the suction when the open suction system was in the volume controlled mode and increased until the $10^{\text {th }}$ minute after the suction, which was consistent with the results of the present study.

According to the resistance and Ppeak results obtained from the present study, in repeated measurements performed in all the suction techniques, respiratory resistance and Ppeak values decreased statistically significantly after the suction compared to the baseline values in patients $(\mathrm{p}<0.05)$ (Figure 1).

The decrease in the resistance and Ppeak values as a result of the suction application is an expected result indicating that the treatment is effective ${ }^{23}$. Therefore, it was concluded that all the suction techniques used in the present study were effective.

Contrary to the present study, in their study investigating the different effects of endotracheal suction in patients with ARDS ${ }^{22}$, Liu et al. found that when the open suction system was in the volume-controlled mode, Ppeak values measured at the $1^{\text {st }}$ and $10^{\text {th }}$ minutes after the suction were higher than those measured during the suction. This increase can be explained by the difference between the suction methods.

\section{Discussion of the Results Indicating the Effect of Suction Techniques on Hemodynamic Indicators}

According to the $\mathrm{EtCO}_{2}$ results in the present study, the comparison of different suction techniques within themselves revealed that the mean $\mathrm{EtCO}_{2}$ values were the lowest at the baseline in the normal suction but highest in the suction with oxygen. However, the mean $\mathrm{EtCO}_{2}$ value measured in the suction technique in which oxygen and SI were administered in combination was higher than were the mean $\mathrm{EtCO}_{2}$ values measured in other techniques (Figures 2). This result was associated with the fact that in patients, oxygen and SI administered before suction obstructed respiration for a long time and thus the patients had a fear of not being able to breathe. In general, the analysis of the $\mathrm{EtCO}_{2}$ values revealed that the measurements during the suction were unstable, but not as much as to cause adverse effects in the clinical conditions of the patients. Based on this impression, it can be said that different suction techniques did not have negative effects on the patient's hemodynamics in terms of $\mathrm{EtCO}_{2}$ and that the difference between the techniques was insignificant. Although in the literature, there is no study whose aim and method were exactly the same as those of the present study, in Demir's (2005) ${ }^{24}$ and Faraji's (2015) ${ }^{25}$ studies performed to compare the open and closed suction systems, carbon 
dioxide pressures in arterial blood gases were studied and similar results were obtained in both methods, which suggests that carbon dioxide pressures do not change much in the closed suction system.

In their study investigating the effect of administration of SI in suction ${ }^{26}$, Akgül and
Akyolcu showed that the level of carbon dioxide pressures in arterial blood gases, though not very significantly, changed negatively in suction with SI. The results of Akgül and Akyolcu's study, though indirectly, are consistent with the results of the present study.

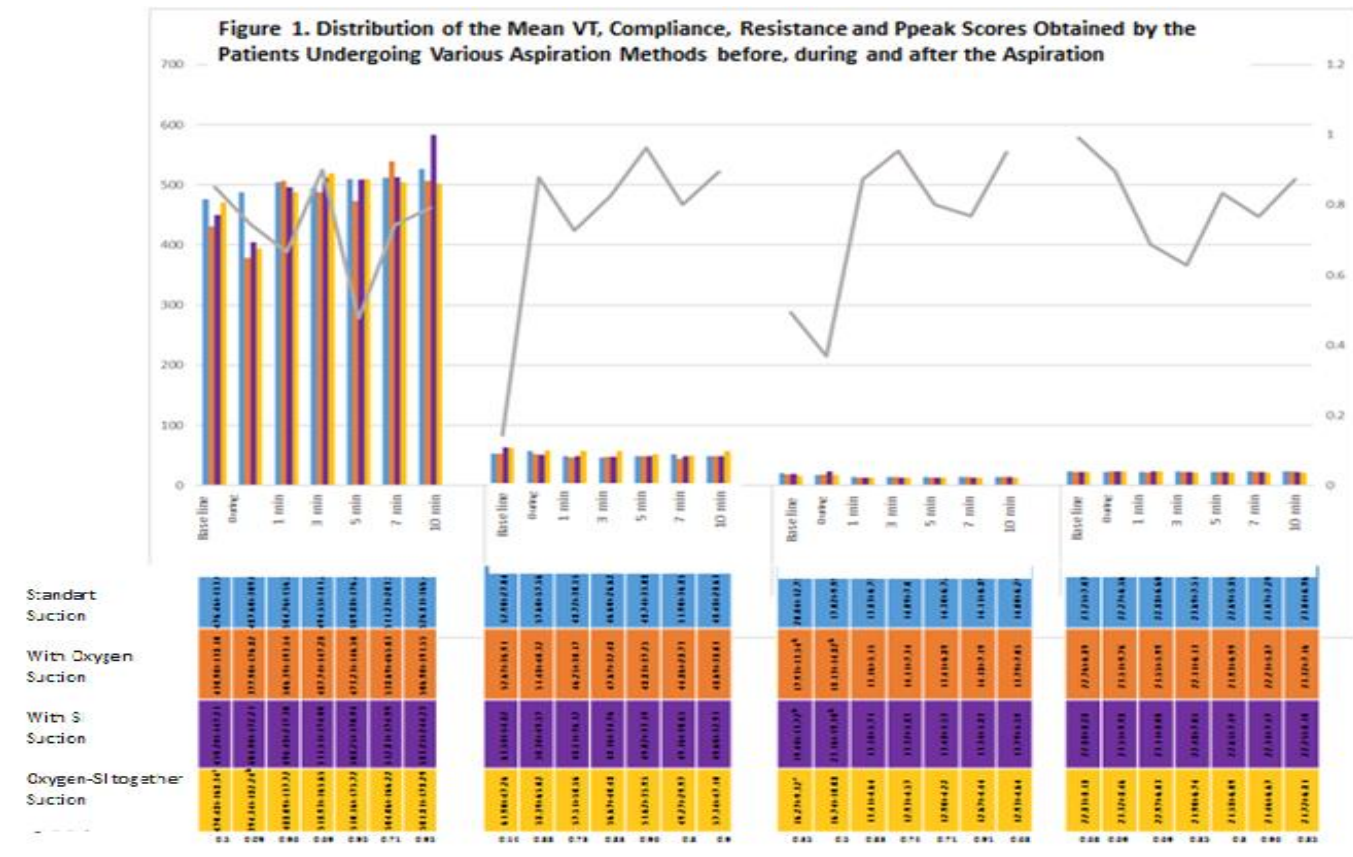

Figure 1: Distribution of the mean VT, compliance, resistance and ppeak scores obtained by the patients undergoing various suction methods before, during and after the suction

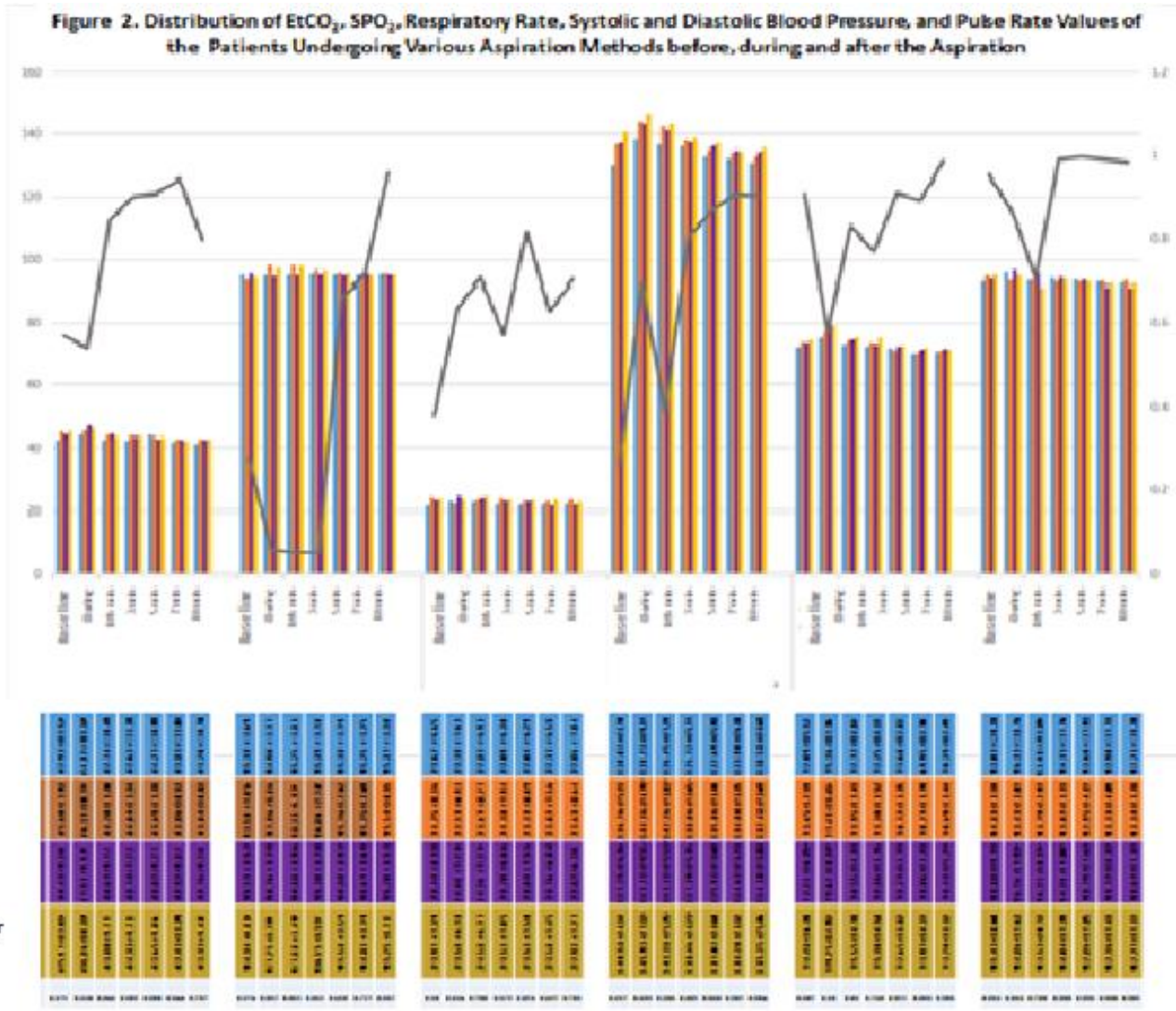


Figure 2: Distribution of $\mathrm{EtCO}_{2}, \mathrm{SPO}_{2}$, respiratory rate, systolic and diastolic blood pressure, and pulse rate values of the patients undergoing various suction methods before, during and after the suction

According to the $\mathrm{SPO}_{2}$ results in the present study, although there were no statistically significant differences between different suction techniques, the difference between the intra-group mean scores was significant in the suction with oxygen, and the mean $\mathrm{SPO}_{2}$ values in this method were lower at the baseline but higher during the suction than those measured in other suction methods (Figures 2). However, the mean $\mathrm{SPO}_{2}$ values in normal suction and suction with SI were never below the normal values. Therefore, it was concluded that in patients with normal $\mathrm{SPO}_{2}$ values, increasing this value by a few units would not be clinically beneficial to the patient and that hyperoxygenation wasn't necessary. Indeed, it was observed that many patients who needed suction experienced discomfort and agitation due to the secretion-related disruption of respiration, and that delaying the suction by one minute to give $100 \%$ oxygen increased the discomfort and agitation present in the patient even further. Although there is no study result supporting this finding in the literature, it is emphasized that hyperoxygenation should not be implemented unless necessary ${ }^{23-25}$. Unlike the present study, in many studies in the literature, it has been stated that the $\mathrm{SPO}_{2}$ values after suction with SI are mostly affected negatively ${ }^{8,22}$. In their study investigating the physiological and respiratory effects of the closed suction system performed in accordance with the AARC guidelines ${ }^{20}$. Seymour concluded that the changes in $\mathrm{SPO}_{2}$ values were not clinically significant, which supports the results of the present study.

According to the respiratory rate results in the present study, the differences between the values measured in all the methods except for the suction with SI were neither clinically nor statistically significant $(\mathrm{p}>0.05)$. Our search in the literature demonstrated a gap regarding this result. However, that the respiratory rate is affected more in the suction with SI is related to the fact that in patients, SI stimulates the cough reflex more and thus compliance with the MV is impaired.

According to the systolic and diastolic blood pressure results in the present study, in all the suction techniques, systolic and diastolic blood pressure values measured during the suction were statistically significantly higher than those measured at the baseline $(p<0.05)$, started to decrease gradually in the following minutes after the suction and became lower than the baseline value at the $10^{\text {th }}$ minute after the suction, and were generally higher in all the suction techniques except in normal suction (Figure 2). Although there is no research result in the literature regarding these findings, higher mean blood pressure values in suction with SI and suction with oxygen and SI in combination have been associated with the stress experienced by the patients. In these patients, both the presence of secretion and the feeling of suffocation due to SI administration caused an increase in blood pressure, but that the increase was within normal limits and fell below the baseline value within the 10 minutes after the suction suggested that different suction techniques generally had no negative effects on patients' hemodynamics.

According to the pulse rate results in the present study, the highest pulse rate values were measured in normal suction and suction with SI during the suction but this elevation in pulse rate was within normal limits (Figures 2). In Afshari et al.'s ${ }^{21}$, study comparing open and closed suction systems in patients undergoing $\mathrm{MV}$, the pulse rate first increased slightly but then decreased below the baseline value. However this increase and decrease were within normal limits, as in the present study. Based on the results obtained from the present study, it can be said that different suction techniques do not generally have a negative effect on the cardiopulmonary indicators of the patients.

\section{Discussion Regarding the Study Results Indicating the Effects of Suction Techniques on the Feelings and Pain Experienced by the Patients}

The pain assessment in different suction techniques demonstrated that the pain level increased during suction, but that the pain level then became lower than the baseline value in patients and that the differences between the mean scores were statistically significant $(\mathrm{p}<0.05)$ (Table 2$)$. On the other hand, it was observed that there were no statistically significant differences between different suction techniques.

In the literature, there are numerous studies whose results were consistent with the results of the present study indicating that suction was the cause of pain ${ }^{27}$. In other studies, it has also been reported that endotracheal suction causes pain and that the presence of an endotracheal tube is the cause of pain and discomfort in patients ${ }^{28}$. In Rotondi et al.'s study conducted to demonstrate discomfort due to endotracheal tube and pain, the patients who were aware that they had an endotracheal tube and that they stayed in the intensive care unit stated that they had endotracheal tube-related pain. In addition to these results, in the present study, that most of 
the patients stated that they had sore throat even when they did not undergo suction also suggests that the pain experienced could not be attributed only to suction but also to the presence of an endotracheal tube.

The analysis of the feelings experienced by the patients revealed that there was no difference between suction techniques in terms of patient comfort (Table 1), and that the patients drew attention to relaxation they enjoyed after suction despite the discomfort they experienced during suction. Although in the literature, there are no studies whose results are related to these findings, it can be said that tracheal suction ensures the maintenance of airway patency and oxygenation, even though it is discomforting.

\section{CONCLUSION}

The study demonstrated that when our suction was performed appropriately with correct tools, there were no statistically significant differences between the different techniques in terms of the parameters examined. The study also demonstrated that if each suction technique was studied in itself, there were statistically significant differences between the suction phases, but that the values leading to differences were within normal limits, and that different suction techniques affected the patients' hemodynamics, cardiopulmonary indicators and comfort in a similar manner. It was found that the standard suction technique could be better tolerated by the patients, and that the administration of oxygen and SI individually or in combination immediately before suction caused anxiety in patients and affected study parameters statistically significantly.

Based on the results obtained from the present study, it is recommended that the suction method should be chosen according to what the clinical condition of a patient requires, that hyperoxygenation should not be used routinely for every patient before and after suction in the closed suction system, that SI should not be routinely used because it increases the stress and discomfort experienced by the patients during suction. There are no studies evaluating different suction methods in terms of the feeling and comfort experienced by the patient during the procedurePutting this knowledge into practice is important for patient's safety and comfort.

\section{Acknowledgment}

I would like to thank the intensive care nurses Derya DEDE and Seher AK, who voluntarily supported the recording of the data in this study, and Ziynet Çınar, Faculty Member of the
Department of Basic Medical Sciences / Biostatistics, who contributed greatly to the statistical analysis of the study.

Funding : This research received no specific grant from any funding agency in the public, commercial, or not-for-profit sectors .

Conflict of interest: The authors declare no conflict of interest in this investigator led research

\section{Chart. Application Stages of the Standard Closed Suction}

1. The procedure was explained to the patient and his/her verbal informed consent was obtained.

\section{Hand hygiene was ensured.}

3. Whether the patient was suitable for the study was re-evaluated. (In terms of the presence of paralysis, sedation use, consciousness, presence of bronchospasm, etc.)

4. Whether the patients suffered pain, and how severe the current pain was were determined using the pain scale.

\section{A $10-20$ cc SI injection was prepared.}

6 . The aspirator was prepared for the suction. The vacuum pressure was set $(-120 \mathrm{mmHg})$ and checked to find out whether it worked.

7. The SI injector prepared was attached to the washing port of the catheter. The safety valve between the tube and the catheter in the closed suction was opened.

8. The curved end of the closed suction catheter directed towards the right side of the patient was advanced in the catheter tube.

9. When encountered with resistance, the catheter was not pushed forward to advance but was pulled back about $1 \mathrm{~cm}$.

10. The catheter was slowly withdrawn by pressing on the vacuum control valve of the closed suction system catheter.

11. The intervention was repeated after a $10 \mathrm{sec}$. interval.

12. The same process was performed twice by turning the tip of the closed system suction catheter to the left.

13. The safety valve of the catheter was closed and the catheter was washed with the SI in the washing injector and the process was terminated.

14. While the procedure was performed by the researcher, the same parameters were re-recorded and continued at $1,3,5,7$, and 10 minutes after the procedure. The record keeping and interviewing of 
the patients were performed by the same person in all the procedures. The hands were washed.

15. The materials were disposed appropriately.

16. The procedure was recorded.

\section{Suction Method Performed with 100\% Oxygen}

The steps 1-8 in the general suction application were performed in the same way in the suction method with oxygen. After the 7th and 13th steps, the patient was given $100 \%$ oxygen through the MV for $1 \mathrm{~min}$

\section{Suction Method Performed with SI}

The first 11 steps in the general suction application were performed in the same way in the suction method with SI. Then while the procedure was repeated, the catheter was advanced through the tube about 3 fingerbreadths. Then the $5 \mathrm{cc}$ SI was delivered with the injector in the washing port and suction was performed by advancing the catheter. The other steps were performed as in the standard suction application.

Suction Method Performed with SI and 100\% Oxygen in Combination

After the steps 1-7 in the general suction application were performed in the same way in this suction method, $100 \%$ oxygen was administered. Then the steps 8-11in the general suction application were performed. After the 11th step, 5 cc SI was delivered with the injector in the washing port and suction was performed by advancing the catheter. The remaining steps in the general suction application were performed in the same way. After the procedure was completed, $100 \%$ oxygen was re-administered,

\section{REFERENCES}

1. Mirnejad R, Jazi FM, Mostafaei S, Sedighi M. Epidemiology of brucellosis in Iran: a comprehensive systematic review and metaanalysis study Microb. Pathog. 2017; 109, 23947

2. Dean AS, Crump L, Greter H, Schelling E, Zinsstag J. Global burden of human brucellosis: a systematic review of disease frequency. PLoS Negl. Trop. Dis. 2012; 6 (10).

3. Mathew C, Stokstad M, Johansen TB, Godfroid $\mathrm{J}$ et al. First isolation, identification, phenotypic and genotypic characterization of Brucella abortus biovar 3 from dairy cattle in Tanzania, BMC Veterinary Research. 2015; 11:156

4. Haghighat S, Yazdannik A. The practice of intensive care nurses using the closed suctioning system: An observational study. Iranian Journal of Nursing and Midwifery Research. 2015; 20(5):619-625.

5. Craven DE, Chroneou A, Zias N, Hjalmarson KI. Ventilator associated tracheobronchitis the impact of targeted antibiotic therapy on patient outcomes. Chest. 2009; 135(2): 521-528.

6. Lucchini A, Zanella A, Bellani G. Tracheal Secretion Management in the Mechanically Ventilated Patient: Comparison of Standard Assessment and an Acoustic Secretion Detector. Respiratory Care. 2011; 56(5):596603.

7. Safdar N, Crnich C.J, Mak D.G. The Pathogenesis of Ventilator Associated Pneumonia. its Relevance to Developing Effective Strategies. For Respir Care. 2005; 50(6):725-739.

8. Guglielminotti J, Alzieu M, Maury E, Guidet B, Offenstadt $\mathrm{G}$. Bedside detection of retained tracheobronchial secretions in patients receiving mechanical ventilation. Clinical Investigations in Critical Care. 2000; 118: 1095-1099.

9. Beuret P, Roux C, Constan A, Mercat A, Brochard L. Discrepancy between guidelines and practice of tracheal suctioning in mechanically ventilated patients; A french multicenter observational study. Intensive care med. 2013; 39: 1335-1336.

10. Hamishehar H, Shadvar K, Taghizahed M, Golzari S.E, Mojtahedzahed M, Soleimanpour $\mathrm{H}$, Mahmoodpoor, A. Ventilator associated pneumonia in patients admitted to intensive care units: Using open or closed endotracheal suctioning. Anesthesiology and Pain Medicine. 2014; 4(5): e21649.

11. Giakoumidakis K, Kostaki Z, Patelarou E, Baltopoulos G, Brokalaki H. Oxygen Saturation and Secretion Weight After Endotracheal Suctioning. British Journal of Nursing. 2011; 20(21). 1344-1345.

12. Khamis G, Waziry O, Abdel- Halim A.B, ElSayed M. Effect of Closed Versus Open Suction System on Cardiopulmonary Parameters Ventilated Neonates. Journal of American Science. 2011; 7(4): 525-534.

13. Pedersen MC, Rosandalh-Neilsen M, Hjerment $\mathrm{J}$, Egerod I. Endotracheal suctioning of the adult intubated patient; What is the evidence? Intensive and Critical Care Nursing 2009; 25(1):21-30.

14. American association for respiratory care: AARC clinical practice guidelines. Endotracheal suctioning of mechanically ventilated patients with artificial airways. Respir Care 2010; 55(6): 758-764. 
15. Corley A, Sharpe N, Caruan RL, Spooner A, Fraser CF. Lung volume changes during cleaning of closed endotracheal suction catheters: A randomized crossover study using electrical impedance tomography. Respiratory care. 2014; 59 (4): 497-503

16. Ntoumenopoulos G. Endotracheal Suctioning May or May Not Have an Impact. Respiratory Care. 2013; 58(10): 1707-1710

17. Bousarri MP, Shirvani Y, Kashani SA, Nasab NM. The effect of expiratory rib cage compression before endotracheal suctioning on the vital sign in patients under mechanical ventilation. Iranian journal of nursing and midwifery research. 2014; 19 (3): 285-289.

18. Day T, Farrnell S, Haynes S, Wainwright S, Wilson-Barnett J. Tracheal suctioning: an exploration of nurses's knowledge and competense in acute and high dependency ward areas. Journal of advanced nursing. 2002; 39(1): 35-45.

19. Jin-Heon J, Sung-Jin N, Young-Jae C, Yeon Joo L, Se Joong K, In-Ae S. et al. A Closed-Suction Catheter with a Pressure Valve Can Reduce Tracheal Mucosal Injury in Intubated Patients. The Korean Journal of Critical Care Medicine. 2014; 29(1):7-12.

20. Palazzo SGC, Soni B. Pressure Changes During Tracheal Suctioning a Laboratory Study. Anaesthesia. 2013; 68. 576-584.

21. Selby PJ, Chapman JA, Etazadi-Amoli J, Dalley D, Boyd NF. The development of a method for assessing the quality of life of cancer patients. British Journol of Cancer . 1984; 50(1):13-22.

22. Eti-Aslan F. Ağr1 Doğası ve Kontrolü (2. Bask1). [The nature and control of pain] İstanbul,Türkiye: Akademisyen Tıp Kitapevi. 2014.

23. Seymour CW, Cross BC, Crok CR, Gallop RL, Fuch BD. Physiologic Impact of Closed Ststem Endotracheal Suctioning in Spontaneously Breathing Patients Receiving Mechanical Ventilation. Respiratory Care 2009; 54: 367-373.
24. Afshari A, Safari M, Oshvandi K, Soltanian A.R. The effect of the open and closed system suctions on cardiopulmonary parameters. Time and costs in patients under mechanical ventilation. Nurs Midwifery Stud. 2014; 3(2):e14097. Epub 2014 Jun 15

25. Liu XW, Jin Y, Ma T, Qu B, Liu Z. Differential Effects of Endotracheal Suctioning on Gas Exchanges in Patients with Acute Respiratory Failure under Pressure-Controlled and VolumeControlled Ventilation. BioMed Research International. 2015; Article ID 941081, 1-6.

26. Sahinoglu H. Yogun Bakim Sorunlari ve Tedavileri. Türkiye Klinikleri. 2. Bask1 Ankara. 2003; 786-815.

27. Demir F, Dramali A. Requirement For $100 \%$ Oxygen Before and After Closed Suction.[Kapalı Emme Öncesi ve Sonrasında\% 100 Oksijen İçin Gereksinim].Journal of Advenced Nursing. 2005; 51(3):245-251.

28. Faraji A, Khatony A, Moradi G, Abdi A, Rezaei M. Open and Closed Endotracheal Suctioning and Arterial Blood Gas Values: A Single-Blind Crossover Randomized Clinical Trial. Hindawi Publishing Corporation Critical Care Research and Practice. 2015 Article ID 470842, 7 pages.

29. Akgül S, Akyolcu N. Endotrakeal Aspirasyonda Serum Fizyolojiğin Etkileri. [The effects of saline on endotracheal suction]. Yoğun Bakım Hemşireliği Dergisi. 2000;. 4 (2), 80-85. Retrieved from http://dergipark.gov.tr/ybhd/issue/26471/27865 4

30. Rotondi AJ, Chelluri L, Sirio C, Mendelsohn A, Schulz R, Belle S, et al. Patients' Recollections of Stressful Experiences While Receiving Prolonged Mechanical Ventilation In An Intensive Care Unit. Critical Care Medicine. 2002; 30(4): 746-752

31. Odhner M, Wegman D, Freeland N, Steinmetz A, Ingersoll G.L. Assessing Pain Control in Nonverbal Critically ill Adults. Dimens Crit Care Nurs. 2003; 22(6):260-267. 